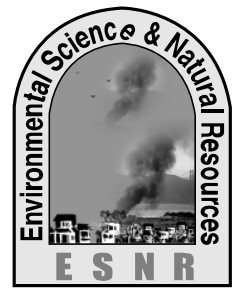

J. Environ. Sci. \& Natural Resources,6(1): 239 - 245, 2013

ISSN 1999-7361

\title{
Salinity Effect on Dry Mass Partitioning in Different Plant Parts and Ion Uptake in Leaves of Rice Mutants
}

\author{
A. B. Puteh ${ }^{1}$ and M. M. A. Mondal ${ }^{1,2}$ \\ ${ }^{1}$ Department of Crop Science, Faculty of Agriculture, Universiti Putra Malaysia, 43400 UPM Serdang, \\ Selangor D. E., Malaysia. \\ ${ }^{2}$ Crop Physiology Division, Bangladesh Institute of Nuclear Agriculture, Mymensingh, Bangladesh
}

\begin{abstract}
The Four levels of sodium chloride induced salinity levels, 0, 6, 9 and $12 \mathrm{dSm}^{-1}$ were imposed at 25 days after planting of six rice mutants. Results indicated that morphological parameters such as plant height and leaf area, dry mass production in different plant parts such as root, stem, leaf and grain yield hill ${ }^{-1}$, physiological characters such as biological yield and harvest index, yield attributes such as number of effective tillers hill ${ }^{-1}$, number of grains panicle ${ }^{-1}$ and 1000 -grain weight, mineral ions in leaves such as potassium and calcium were decreased with gradual increasing of salinity levels while number of non-effective tillers hill ${ }^{-1}$ and $\mathrm{Na}$ content of leaves were increased with increasing soil salinity. The highest value of the above parameters was observed in control and the lowest values of them were observed at $12 \mathrm{dSm}^{-1}$. Generally genotypes having ability to exclude Na from leaves were found salt tolerant in respect of dry mass production in different plant parts and vice versa. Among the genotypes, the dry matter production and yield loss due to salinity was less in RM250-170 and RM250-2080 than that in the others, which further revealed that RM250-170 and RM250-2080 had a greater tolerance to salinity than RM350-130, RM300280, RM250-1080 and IRATOM. The rank of salinity tolerance was: RM250-2080 > RM250-170 > RM250-1080 > IRATOM > RM300-280 > RM350-130.
\end{abstract}

Key words: Dry mass production, Mineral ion, Rice mutant, Salinity stress, Yield attributes

\section{Introduction}

Rice (Oryza sativa L.) is the principal staple food of the people in South and South-East Asia. Among the various factor limiting rice yielding, salinity is one of the oldest and most serious environmental problems in the world. However, salinity problem received very little attention in the past, but due to increased demand for growing more food to feed the booming population of the world, it has became imperative to explore the potentials of these lands. The effective reclamation of the saline soils is difficult and complex due to frequent inundation and tidal flooding. It could be, therefore, being wise to grow the salt tolerant cultivars of rice in the coastal area or for localities where salinity is increasing due to effect of increase seas level. The policy is to develop some rice cultivars that will be adopted in this region for increasing the production of rice. So far, no promising salinity tolerant rice cultivar has been developed for this saline area. Thus this vast land remains fallow and unproductive year around. Therefore, development of salt tolerant rice cultivars is highly demanding to enhance production of rice in South and South-East Asia.

Rice is moderately salt sensitive crop species (Summart et al., 2010). It has been reported that rice at critical level $(4 \mathrm{dS} / \mathrm{m})$ might give normal straw yield (Islam et al., 2004). It exhibits considerable intra-specific variability in resistance to $\mathrm{NaCl}$ salinity (Maiti et al., 2008). Salinity affects the growth of plants by decreasing the rate of water uptake due to osmotic effect, or through ion-specific toxic effects or through nutritional imbalance caused by ion antagonism (Natarajan et al., 2005). Study on the response of rice to salinity stress may be helpful in breeding salt tolerant cultivars by identifying physiological features potential to salinity tolerance. Salt tolerant cultivars had lower $\mathrm{Na}^{+}$and higher $\mathrm{K}^{+}$ content (Mondal et al., 2013). Finding from many works suggested that $\mathrm{Ca}^{++}$uptake, translocation and distribution may be critically affected by salinization (Islam et al., 2007). The effect of soil salinity varies from genotype to genotype (Mondal et al., 2013). Most of the workers reported that salt tolerant genotype showed less accumulation of $\mathrm{Na}^{+}$and $\mathrm{Cl}^{-}$ and maintained its specificity for $\mathrm{K}^{+}$(Cristo et al., 2001; Flowers, 2004; Islam et al., 2004).

Anyway, the productivity of rice can be increased in coastal area by selecting suitable variety. The varieties with higher dry matter production and its proper distribution resulted in higher grain yield. Roots and shoots together constitute the entire plant structure. These two plant parts are competing for water, nutrients and metabolic products. The optimum proportion of dry mass between these parts should be partioned if the final yield is to be maximized (Gorney and Larson, 1989). However, the relation between stem size and root size trends to be constant. A large root system consume reserves and assimilates from a large area which could be used for yield formation while a smaller one limits the absorption of water and minerals and hence photosynthesis. Saline susceptible genotype normally affected more in root growth than shoot growth and consequently lowers economic yield production 
(Alamgir and Ali, 1998). Therefore, there is need to study dry mass partitioning into plant parts under saline condition. Literature on root and shoot growth of rice, dry matter partitioning and their interrelationships under saline condition are few and scanty. Therefore, the present piece of research work was undertaken to assess the effect of salinity stress on dry mass partitioning into different plant parts and mineral ion uptake and its relation with grain yield in rice.

\section{Materials and Methods}

The pot culture experiment was carried out at the glass house of Universiti Putra Malaysia, during the period from 15 November 2012 to 20 April 2013. Geographically the experimental area is located at $102^{\circ} 12^{\prime} \mathrm{N}$ latitude and $101^{\circ} 42^{\prime} \mathrm{E}$ longitudes at the elevation of $31 \mathrm{~m}$ above the sea level. The $\mathrm{pH}$ value, cation exchange capacity (CEC) and electrical conductivity (EC) of the soil were 5.58, 16.30 $\mathrm{meq} / 100 \mathrm{~g}$ soil and $0.36 \mathrm{dSm}^{-1}$, respectively. Five elite rice mutants namely RM350-130, RM300-280, RM250-1080, RM250-170, RM250-2080 developed at BINA and one moderately saline tolerant rice mutant variety, IRATOM were used as planting material.

Inner wall of each perforated plastic pot is covered by a piece of cloth so that soil cannot easily washout. Soils were collected from rice growing field, Tanjung Karang, Selanor, Malaysia. The collected soil was well pulverized and dried in the sun. Plant propagules and inert materials were removed from this soil. The dry soil was thoroughly mixed with well rotten cow dung. This prepared medium was used in filling the pots after well mixing with given amounts of urea, triple superphosphate, muriate of potash and gypsum at the rate of $1.35,1.55,0.0 .82$ and $0.75 \mathrm{~g} \mathrm{pot}^{-1}$ corresponding to $125,150,80$ and $50 \mathrm{~kg} \mathrm{ha}^{-1}$, respectively. Plastic pots of $15 \mathrm{~cm}$ diameter and 20 $\mathrm{cm}$ height were used for the experiment. The pots of the experiment were filled with $3 \mathrm{~kg}$ of soils. The pots were placed in 150-Liters tray type water reservoir for nutrient solution and maintained of salinity. The water depth of the reservoir was $18 \mathrm{~cm}$ and it was always maintained by addition of water at weekly basis. For smaller size of the pots, a Hoagland's solution was used weekly in water reservoir for normal plant growth and development.

The experiment was designed in a Split Plot arrangement with four replications in which salinity treatments were the main factor and genotypes the sub-factor. Each pot contained one hill and denoted a replication. Seeds were sown on 15 November, 2012 and plants were thinned to one plant per pot at 25 days after sowing and then the pots were placed water reservoir tray. The treatments of the experiment were:
Six rice mutants viz., RM350-130, RM300-280, RM250-1080, RM250-170, RM250-2080 and IRATOM, and four levels of salinity viz., 0, 6, 9 and $12 \mathrm{dS} \mathrm{m}^{-1}$. The first five genotypes were elite mutants developed at BINA. The sixth genotype was the widely cultivated moderately salt tolerant mutant variety. The required quantities of commercial salts were applied to water reservoir at 25 days after sowing to impose salinity. To maintain specific salinity level, a high salinity $\left(30 \mathrm{dS} \mathrm{m}^{-1}\right)$ solution was poured slowly to water reservoir until getting a desired salinity. The salinity levels of the water reservoir was monitored weekly by EC meter (Model: Z865, SCHOTT Instruments, Germany) and saline solution was added (when necessary) to maintained required salinity level in the reservoir. Weeding was done as and when necessary. Water was supplied to water reservoir as and when needed to maintain a specific water height to ensure sufficient moisture for the normal growth of the crops.

Sodium, potassium and calcium contents were determined from leaves. Analysis of mineral ion contents was carried out after extracting of given amount of plant sample in nitric acid for at least $2 \mathrm{~h}$ at $90{ }^{\circ} \mathrm{C}$. Alkali cations were determined by atomic absorption spectrophotometry (AA-660, Shimadzu, Japan). At harvest, morphological parameters, dry mass weight in different plant parts, yield attributes and grain yield was recorded. Harvest index was calculated by dividing economic yield to biological yield of plant multiplied with 100 and expressed in percentage. The collected data were analyzed statistically following the analysis of variance (ANOVA) technique and the mean differences were adjudged by Duncan's Multiple Range Test (DMRT) using the statistical computer package program, MSTAT-C.

\section{Results and Discussion}

\section{Morphological characters and yield attributes}

The effect of different levels of salinity was significant on plant height, leaf area (LA) hill ${ }^{-1}$, and effective and non-effective tiller number hill $^{-1}$, number of filled grains panicle ${ }^{-1}, 1000$-grain weight and grain weight hill ${ }^{-1}$ (Table 1). Results indicated that all the morphological parameters and yield attributes decreased with increased salinity levels except number of non-effective tillers hill ${ }^{-1}$. The noneffective tiller number hill $^{-1}$ increased with increasing salinity levels. The highest plant height, LA, number of effective tillers hill ${ }^{-1}$, number of filled grains panicle $^{-1}$ and 1000-grain weight was observed in control plant and there by grain yield followed by 6 $\mathrm{dSm}^{-1}$. The lowest values of the above parameters were observed at $12 \mathrm{dSm}^{-1}$ salinity. However, reduced plant height and LA hill ${ }^{-1}$ under salinity condition 
might be due to inhibited photosynthesis under salinity stress (Mondal et al., 2013) that causes less amount of nutrients uptake by the plant (Mahmood et al., 2009) resulting slow plant growth rate.

Interaction between salinity levels and genotypes had significant effect on all the studied morphological parameters, yield attributes and grain yield (Table 2). Results revealed that all the morphological parameters and yield attributes deceased with increasing salinity levels (except number of noneffective tillers hill ${ }^{-1}$ ) in all the studied genotypes but decrement was not similar among the genotypes. The decrease of the morphological parameters like plant height and LA, and yield attributes like number of effective tillers hill $^{-1}$, number of filled grains panicle ${ }^{-1}$ and 1000-grain weight due to salinity were less in the mutants, RM250-170 and RM250-2080 than the others. On the other hand, the decrease of the above studied parameters due to salinity was the highest in RM350-130. These results are consistent with Islam et al. (2004) and Mondal et al. (2013) who reported that salinity tolerant genotypes had less negative effect on morpho-physiological characters and yield attributes than the susceptible ones.

Table 1. Salinity effect on morphological characters and yield attributes in rice mutants

\begin{tabular}{|c|c|c|c|c|c|c|c|}
\hline $\begin{array}{l}\text { Salinity } \\
\text { levels } \\
(\mathrm{dS} / \mathrm{m})\end{array}$ & $\begin{array}{l}\text { Plant } \\
\text { height } \\
(\mathrm{cm})\end{array}$ & $\begin{array}{l}\text { Leaf area } \\
\text { hill }^{-1}\left(\mathrm{~cm}^{2}\right)\end{array}$ & $\begin{array}{l}\text { Effective } \\
\text { tillers } \\
\text { hill }^{-1} \text { (no.) }\end{array}$ & $\begin{array}{l}\text { Non- } \\
\text { effective } \\
\text { tillers hill }^{-1} \\
\text { (no.) }\end{array}$ & $\begin{array}{l}\text { Filled } \\
\text { grains } \\
\text { panicle } \\
\text { (no.) }\end{array}$ & $\begin{array}{l}\text { 1000-grain } \\
\text { weight }(\mathrm{g})\end{array}$ & $\begin{array}{l}\text { Grain } \\
\text { weight } \\
\text { hill }^{-1}(\mathrm{~g})\end{array}$ \\
\hline 0 & $85.21 \mathrm{a}$ & $1231 \mathrm{a}$ & $20.02 \mathrm{a}$ & $2.54 \mathrm{c}$ & $93.64 \mathrm{a}$ & $23.95 \mathrm{a}$ & $46.34 \mathrm{a}$ \\
\hline 6 & $84.81 \mathrm{a}$ & $1113 b$ & $16.92 \mathrm{~b}$ & $3.55 \mathrm{~b}$ & $83.83 \mathrm{~b}$ & $23.68 \mathrm{a}$ & $40.04 \mathrm{~b}$ \\
\hline 9 & $78.22 \mathrm{~b}$ & $700 \mathrm{c}$ & $13.72 \mathrm{c}$ & $3.79 \mathrm{~b}$ & $65.68 \mathrm{c}$ & $22.74 \mathrm{~b}$ & $29.12 \mathrm{c}$ \\
\hline 12 & $72.40 \mathrm{c}$ & $488 \mathrm{~d}$ & $9.95 \mathrm{~d}$ & $4.87 \mathrm{a}$ & $46.38 \mathrm{~d}$ & $21.60 \mathrm{c}$ & $16.74 \mathrm{~d}$ \\
\hline F-test & $* *$ & $* *$ & $* *$ & $* *$ & $* *$ & $* *$ & $* *$ \\
\hline $\mathrm{CV}(\%)$ & 3.44 & 6.30 & 9.41 & 9.67 & 4.50 & 3.66 & 7.67 \\
\hline
\end{tabular}

In a column, figures having the same letter (s) do not differ significantly as per DMRT;

$* *=$ Significant at $1 \%$ level of probability

\section{Dry matter production and distribution in different plant parts}

The effect of salinity on dry mass production and distribution was significant (Table 3). Results showed that root weight, stem weight, leaf weight, grain weight and biological yield (BY) hill ${ }^{-1}$ and harvest index (HI) decreased with increasing salinity levels. The highest root weight, stem weight, leaf weight, grain weight and $\mathrm{BY}$ hill $^{-1}$ and $\mathrm{HI}$ were recorded in control plant followed by $6 \mathrm{dSm}^{-1}$. In contrast, the lowest root weight, stem weight, leaf weight, grain weight and BY hill ${ }^{-1}$ and $\mathrm{HI}$ were recorded in $12 \mathrm{dSm}^{-}$ ${ }^{1}$. These results indicate that salinity seriously hampered dry matter accumulation in different plant parts of rice. The reduction in dry matter accumulation in different plant parts under saline condition might be due to lower amount of photosynthetic apparatus (chlorophyll), lower stomatal conductance and lower uptake of nutrients from soil (Mondal et al., 2013). This result agrees with the findings of Moradi and Ismail (2007) in rice. A decrease in chlorophyll concentration of leaves in salinized plants could be attributed to increase activity of the chlorophyll degrading enzyme, chlorophyllase and the production of the said enzyme enhance by deficiency of $\mathrm{K}^{+}$(Reddy and Vora, 1986).
Similar phenomenon may be happened in the present experiment.

The interaction effect of salinity levels and genotypes in relation to dry matter production in different plant parts in rice was significant (Table 4). Results showed that root weight, stem weight, leaf weight, grain weight and BY hill ${ }^{-1}$ and $\mathrm{HI}$ decreased with increasing salinity levels in all the genotypes but the decrement was not similar among the genotypes. The decrease of root weight, stem weight, leaf weight, grain weight and $\mathrm{BY}$ hill $^{-1}$ and $\mathrm{HI}$ due to salinity was less in RM250-170 and RM250-2080 with being the lowest in RM250-170 indicating these genotypes are salt tolerant in physiological activities. The higher decrease in root weight, stem weight, leaf weight, grain weight and $\mathrm{BY}$ hill $^{-1}$ and $\mathrm{HI}$ due to salinity was recorded in RM350-130, RM300-280 and IRATOM with being the highest in RM350-130 indicating these genotypes are salt susceptible in physiological activities.

Total DM production is determined by magnitude of DM partitioning into root, stem and leaf growth. In RM250-2080 and RM250-170, the high yielding mutants under saline condition, thus increased DM partitioning into root, stem and leaf growth resulted 
Table 2. Effect of interaction of salinity levels and genotypes on morphological characters in rice

\begin{tabular}{|c|c|c|c|c|c|c|c|c|}
\hline \multicolumn{2}{|l|}{ Interaction } & \multirow{2}{*}{$\begin{array}{l}\text { Plant } \\
\text { height } \\
(\mathrm{cm})\end{array}$} & \multirow{2}{*}{$\begin{array}{l}\text { Leaf area } \\
\text { hill }^{-1} \\
\left(\mathrm{~cm}^{2}\right)\end{array}$} & \multirow{2}{*}{$\begin{array}{l}\text { Effective } \\
\text { tillers } \\
\text { hill }^{-1} \\
\text { (no.) }\end{array}$} & \multirow{2}{*}{$\begin{array}{l}\text { Non- } \\
\text { effective } \\
\text { tillers } \\
\text { hill }^{-1} \text { (no) }\end{array}$} & \multirow{2}{*}{$\begin{array}{l}\text { Filled } \\
\text { grains } \\
\text { panicle } \\
\text { (no.) }\end{array}$} & \multirow{2}{*}{$\begin{array}{l}1000- \\
\text { grain } \\
\text { weight } \\
(\mathrm{g})\end{array}$} & \multirow{2}{*}{$\begin{array}{l}\text { Grain } \\
\text { weight } \\
\text { hill }^{-1}(\mathrm{~g})\end{array}$} \\
\hline $\begin{array}{l}\text { Genotypes/ } \\
\text { variety }\end{array}$ & $\begin{array}{l}\text { Salinity } \\
\text { levels } \\
(\mathrm{dS} / \mathrm{m})\end{array}$ & & & & & & & \\
\hline \multirow[t]{4}{*}{ RM350-130 } & 0 & 76.20 & 1005 & 15.80 & 2.70 & 71.52 & 25.55 & 36.20 \\
\hline & 6 & 74.00 & 950 & 12.50 & 3.75 & 68.40 & 25.30 & 30.09 \\
\hline & 9 & 66.20 & 487 & 9.10 & 5.90 & 44.88 & 23.10 & 18.20 \\
\hline & 12 & 59.00 & 370 & 4.50 & 6.25 & 18.71 & 20.00 & 6.100 \\
\hline \multirow[t]{4}{*}{ RM300-280 } & 0 & 90.66 & 1310 & 20.81 & 3.69 & 95.70 & 20.66 & 47.88 \\
\hline & 6 & 88.33 & 1190 & 17.55 & 4.70 & 82.33 & 20.25 & 40.76 \\
\hline & 9 & 80.75 & 650 & 12.00 & 5.75 & 74.00 & 19.81 & 30.07 \\
\hline & 12 & 76.39 & 495 & 8.30 & 6.30 & 62.90 & 19.55 & 10.50 \\
\hline \multirow[t]{4}{*}{ RM250-1080 } & 0 & 83.20 & 1180 & 19.10 & 2.45 & 95.16 & 22.95 & 43.15 \\
\hline & 6 & 81.70 & 1000 & 16.50 & 3.10 & 86.70 & 22.75 & 36.60 \\
\hline & 9 & 75.50 & 670 & 14.00 & 2.50 & 71.88 & 22.15 & 29.60 \\
\hline & 12 & 70.00 & 475 & 10.20 & 3.80 & 58.81 & 21.86 & 18.30 \\
\hline \multirow[t]{4}{*}{ RM250-170 } & 0 & 96.30 & 1290 & 22.40 & 1.60 & 99.64 & 21.60 & 46.30 \\
\hline & 6 & 92.50 & 1195 & 19.50 & 3.67 & 94.66 & 21.45 & 43.60 \\
\hline & 9 & 83.75 & 870 & 17.10 & 3.40 & 71.74 & 21.25 & 32.66 \\
\hline & 12 & 79.00 & 530 & 13.00 & 5.00 & 48.72 & 20.55 & 25.13 \\
\hline \multirow[t]{4}{*}{ RM250-2080 } & 0 & 98.20 & 1373 & 21.00 & 2.50 & 106.8 & 27.75 & 56.69 \\
\hline & 6 & 94.58 & 1270 & 18.50 & 3.50 & 95.30 & 27.51 & 52.40 \\
\hline & 9 & 85.40 & 890 & 16.50 & 2.20 & 80.40 & 26.95 & 41.10 \\
\hline & 12 & 80.00 & 595 & 14.00 & 3.00 & 56.56 & 26.00 & 27.50 \\
\hline \multirow[t]{4}{*}{ IRATOM } & 0 & 86.70 & 1230 & 21.00 & 2.30 & 93.00 & 25.20 & 47.80 \\
\hline & 6 & 82.71 & 1070 & 17.00 & 2.60 & 75.61 & 24.85 & 36.77 \\
\hline & 9 & 77.75 & 634 & 13.60 & 3.00 & 51.20 & 23.20 & 23.11 \\
\hline & 12 & 70.00 & 465 & 9.700 & 4.90 & 32.55 & 21.65 & 12.90 \\
\hline F-test & & $* *$ & $* *$ & * & $* *$ & $* *$ & $* *$ & $* *$ \\
\hline $\operatorname{LSD}_{(0.05)}$ & & 4.53 & 91.27 & 2.34 & 0.59 & 5.34 & 1.38 & 4.16 \\
\hline $\mathrm{CV}(\%)$ & & & 3.44 & 6.30 & 9.41 & 9.67 & 4.50 & 7.67 \\
\hline
\end{tabular}

$*, * *=$ Significant at $5 \%$ and $1 \%$ level of probability, respectively

Table 3. Salinity effect on dry mass production and distribution in different parts of canopy in rice mutants

\begin{tabular}{c|l|l|l|l|l|l}
\hline $\begin{array}{l}\text { Salinity } \\
\text { levels }(\mathrm{dS} / \mathrm{m})\end{array}$ & $\begin{array}{l}\text { Root weight } \\
\text { hill }^{-1}(\mathrm{~g})\end{array}$ & $\begin{array}{l}\text { Stem weight } \\
\text { hill }^{-1}(\mathrm{~g})\end{array}$ & $\begin{array}{l}\text { Leaf weight } \\
\text { hill }^{-1}(\mathrm{~g})\end{array}$ & $\begin{array}{l}\text { Grain weight } \\
\text { hill }^{-1}(\mathrm{~g})\end{array}$ & $\begin{array}{l}\text { Biological } \\
\text { yield hill }^{-1}(\mathrm{~g})\end{array}$ & $\begin{array}{l}\text { Harvest index } \\
(\%)\end{array}$ \\
\hline 0 & $8.77 \mathrm{a}$ & $39.97 \mathrm{a}$ & $17.72 \mathrm{a}$ & $46.34 \mathrm{a}$ & $112.7 \mathrm{a}$ & $41.49 \mathrm{a}$ \\
6 & $7.95 \mathrm{~b}$ & $35.53 \mathrm{~b}$ & $15.98 \mathrm{~b}$ & $40.04 \mathrm{~b}$ & $99.67 \mathrm{~b}$ & $40.60 \mathrm{a}$ \\
9 & $5.68 \mathrm{c}$ & $28.47 \mathrm{c}$ & $12.12 \mathrm{c}$ & $29.12 \mathrm{c}$ & $73.94 \mathrm{c}$ & $38.70 \mathrm{~b}$ \\
12 & $4.00 \mathrm{~d}$ & $20.49 \mathrm{~d}$ & $8.122 \mathrm{~d}$ & $16.74 \mathrm{~d}$ & $49.52 \mathrm{~d}$ & $32.80 \mathrm{c}$ \\
\hline F-test & $* *$ & $* *$ & $* *$ & $* *$ & $* *$ & $* *$ \\
\hline CV $(\%)$ & 6.11 & 8.45 & 8.32 & 7.67 & 8.18 & 5.98 \\
\hline
\end{tabular}

In a column, figures having the same letter (s) do not differ significantly as per DMRT;

$* *=$ Significant at $1 \%$ level of probability

greater TDM production in these two genotypes than in low yielding ones. Among the different plant parts, under saline condition, seed weight contributed the highest $(48.5 \%)$ of total dry mass production in RM250-2080 followed by RM250-170 (37.74\%). In contrast, RM300-280 contributed the lowest (22.45\%) of the TDM. This result indicate that under saline condition, two mutants, RM250-2080 and RM250170 has better dry matter portioning to economic yield than the other four mutants, RM350-130, RM300-280, RM250-1080 and IRATOM. 
Table 4. Effect of interaction of salinity levels and genotypes on dry mass production and distribution in different parts of canopy in rice

\begin{tabular}{|c|c|c|c|c|c|c|c|}
\hline \multicolumn{2}{|l|}{ Interaction } & \multirow{2}{*}{$\begin{array}{l}\text { Root } \\
\text { weight } \\
\text { hill }^{-1}(\mathrm{~g})\end{array}$} & \multirow{2}{*}{$\begin{array}{l}\text { Stem } \\
\text { weight } \\
\text { hill }^{-1}(\mathrm{~g})\end{array}$} & \multirow{2}{*}{$\begin{array}{l}\text { Leaf } \\
\text { weight } \\
\text { hill }^{-1}(\mathrm{~g})\end{array}$} & \multirow{2}{*}{$\begin{array}{l}\text { Grain } \\
\text { weight } \\
\text { hill }^{-1}(\mathrm{~g})\end{array}$} & \multirow{2}{*}{$\begin{array}{l}\text { Biological } \\
\text { yield } \\
\text { hill }^{-1}(\mathrm{~g})\end{array}$} & \multirow{2}{*}{$\begin{array}{l}\text { Harvest } \\
\text { index }(\%)\end{array}$} \\
\hline $\begin{array}{l}\text { Genotypes/ } \\
\text { variety }\end{array}$ & $\begin{array}{l}\text { Salinity } \\
\text { levels } \\
(\mathrm{dS} / \mathrm{m})\end{array}$ & & & & & & \\
\hline \multirow[t]{4}{*}{ RM350-130 } & 0 & 6.10 & 23.60 & 11.40 & 36.20 & 77.30 & 46.83 \\
\hline & 6 & 5.32 & 20.90 & 10.30 & 30.09 & 67.60 & 45.71 \\
\hline & 9 & 2.35 & 14.10 & 6.170 & 18.20 & 40.79 & 44.62 \\
\hline & 12 & 1.72 & 7.990 & 3.400 & 6.100 & 19.21 & 31.75 \\
\hline \multirow[t]{4}{*}{ RM300-280 } & 0 & 10.1 & 47.47 & 26.16 & 47.88 & 130.9 & 36.58 \\
\hline & 6 & 9.74 & 42.10 & 24.72 & 40.76 & 117.3 & 34.74 \\
\hline & 9 & 6.66 & 35.42 & 19.91 & 30.07 & 79.09 & 32.67 \\
\hline & 12 & 4.30 & 20.50 & 10.48 & 10.50 & 46.78 & 22.45 \\
\hline \multirow[t]{4}{*}{ RM250-1080 } & 0 & 8.40 & 40.84 & 15.90 & 43.15 & 108.3 & 39.84 \\
\hline & 6 & 7.74 & 36.55 & 14.96 & 36.60 & 95.85 & 38.18 \\
\hline & 9 & 5.85 & 30.00 & 11.86 & 29.60 & 78.64 & 37.28 \\
\hline & 12 & 4.65 & 22.10 & 9.030 & 18.30 & 54.08 & 33.84 \\
\hline \multirow[t]{4}{*}{ RM250-170 } & 0 & 7.80 & 38.68 & 16.55 & 46.30 & 109.3 & 42.35 \\
\hline & 6 & 7.21 & 36.70 & 15.00 & 43.60 & 102.5 & 42.53 \\
\hline & 9 & 5.51 & 31.50 & 12.50 & 32.66 & 82.17 & 39.75 \\
\hline & 12 & 4.63 & 27.00 & 9.830 & 25.13 & 66.59 & 37.74 \\
\hline \multirow[t]{4}{*}{ RM250-2080 } & 0 & 11.0 & 45.60 & 17.00 & 56.69 & 130.3 & 43.51 \\
\hline & 6 & 9.88 & 41.72 & 15.60 & 52.40 & 119.6 & 43.81 \\
\hline & 9 & 8.30 & 34.20 & 11.86 & 41.10 & 98.46 & 42.05 \\
\hline & 12 & 6.00 & 26.45 & 9.100 & 27.50 & 69.05 & 39.82 \\
\hline \multirow{4}{*}{ IRATOM } & 0 & 9.24 & 43.62 & 19.33 & 47.80 & 120.0 & 39.84 \\
\hline & 6 & 7.83 & 35.22 & 15.31 & 36.77 & 95.15 & 38.64 \\
\hline & 9 & 5.40 & 25.60 & 10.40 & 23.11 & 64.51 & 35.82 \\
\hline & 12 & 2.70 & 18.90 & 6.89 & 12.90 & 41.39 & 31.17 \\
\hline F-test & & $* *$ & $* *$ & $* *$ & $* *$ & $* *$ & $* *$ \\
\hline $\operatorname{LSD}_{(0.05)}$ & & 0.66 & 4.31 & 1.84 & 4.16 & 11.27 & 3.77 \\
\hline $\mathrm{CV}(\%)$ & & 6.11 & 8.45 & 8.32 & 7.67 & 8.18 & 5.98 \\
\hline
\end{tabular}

$* *=$ Significant at $1 \%$ level of probability

\section{Mineral ion content in leaves}

The effect of salinity on $\mathrm{Na}^{+}, \mathrm{K}^{+}$and $\mathrm{Ca}^{++}$content in leaves was significant (Table 5). Results showed that $\mathrm{Na}^{+}$ion content in leaves increased with increasing salinity levels while reverse trend was observed in case of $\mathrm{K}^{+}$and $\mathrm{Ca}^{++}$uptake. The excess amount of $\mathrm{Na}$ creates a toxic effect on plant metabolic processes (Karim et al., 1992) and susceptible genotypes having high amount of $\mathrm{Na}^{+}$with less amount of $\mathrm{K}^{+}$and $\mathrm{Ca}^{++}$.

The interaction effect of salinity levels and genotypes on $\mathrm{Na}^{+}, \mathrm{K}^{+}$and $\mathrm{Ca}^{++}$content in leaves was significant (Table 6). Results showed that $\mathrm{Na}^{+}$uptake in straw increased with increasing $\mathrm{Na}$ concentration in growth media in all the genotypes but the increment of $\mathrm{Na}^{+}$ accumulation was comparatively less in saline tolerant genotypes (RM250-2080 and RM250-170) than susceptible genotypes (RM350-130, RM300280, RM250-1080 and IRATOM). Less reduction in $\mathrm{K}^{+}$and $\mathrm{Ca}^{++}$accumulation in plant tissue due to salinity were also observed in saline tolerant genotypes (RM250-2080 and RM250-170) than the susceptible ones. These results are consistent with the findings of many workers (Karim et al., 1992; Pandey and Sharma, 2002; Islam et al., 2007; Mondal et al., 2013). Dionisio-Sese and Tobita (2000) opined that there was an inverse relationship between shoot $\mathrm{Na}^{+}$ concentration and salt tolerance. The salt-sensitive mutants RM350-130, RM300-280 and IRATOM exhibited significant increase in $\mathrm{Na}^{+}$content with increasing salinity levels in soil, whereas the salttolerant genotypes RM250-2080 and RM250-170 did not show pronounce accumulation (Table 6). 
Table 5. Mean effect of different salinity levels on mineral ion concentration in leaves of six rice mutants

\begin{tabular}{l|l|l|l}
\hline Salinity levels $(\mathrm{dS} / \mathrm{m})$ & $\begin{array}{l}\text { Sodium } \\
(\%)\end{array}$ & $\begin{array}{l}\text { Potassium } \\
(\%)\end{array}$ & $\begin{array}{l}\text { Calcium } \\
(\%)\end{array}$ \\
\hline 0 & $0.068 \mathrm{~d}$ & $0.660 \mathrm{a}$ & $0.920 \mathrm{a}$ \\
6 & $0.088 \mathrm{c}$ & $0.625 \mathrm{a}$ & $0.832 \mathrm{~b}$ \\
9 & $0.099 \mathrm{~b}$ & $0.552 \mathrm{~b}$ & $0.695 \mathrm{c}$ \\
12 & $0.154 \mathrm{a}$ & $0.467 \mathrm{c}$ & $0.593 \mathrm{~d}$ \\
\hline F-test & $* *$ & $* *$ \\
\hline CV $(\%)$ & $* *$ & 9.60 & 6.48 \\
\hline$* *=$ Significant at $1 \%$ level of probability
\end{tabular}

Table 6. Effect of interaction of salinity levels and genotypes on on mineral ion concentration in leaves of rice

\begin{tabular}{|c|c|c|c|c|}
\hline \multicolumn{2}{|l|}{ Interaction } & \multirow[b]{2}{*}{$\begin{array}{l}\text { Sodium } \\
(\%)\end{array}$} & \multirow[b]{2}{*}{ Potassium (\%) } & \multirow[b]{2}{*}{$\begin{array}{l}\text { Calcium } \\
(\%)\end{array}$} \\
\hline $\begin{array}{l}\text { Genotypes/ } \\
\text { variety }\end{array}$ & $\begin{array}{l}\text { Salinity levels } \\
(\mathrm{dS} / \mathrm{m})\end{array}$ & & & \\
\hline \multirow[t]{4}{*}{ RM350-130 } & 0 & 0.090 & 0.60 & 0.80 \\
\hline & 6 & 0.120 & 0.53 & 0.74 \\
\hline & 9 & 0.160 & 0.46 & 0.62 \\
\hline & 12 & 0.190 & 0.40 & 0.47 \\
\hline \multirow[t]{4}{*}{ RM300-280 } & 0 & 0.082 & 0.52 & 0.88 \\
\hline & 6 & 0.090 & 0.53 & 0.72 \\
\hline & 9 & 0.120 & 0.44 & 0.60 \\
\hline & 12 & 0.160 & 0.38 & 0.50 \\
\hline \multirow[t]{4}{*}{ RM250-1080 } & 0 & 0.060 & 0.65 & 0.92 \\
\hline & 6 & 0.080 & 0.63 & 0.84 \\
\hline & 9 & 0.011 & 0.56 & 0.73 \\
\hline & 12 & 0.140 & 0.48 & 0.67 \\
\hline \multirow[t]{4}{*}{ RM250-170 } & 0 & 0.057 & 0.73 & 1.02 \\
\hline & 6 & 0.070 & 0.72 & 0.96 \\
\hline & 9 & 0.090 & 0.65 & 0.81 \\
\hline & 12 & 0.120 & 0.50 & 0.75 \\
\hline \multirow{4}{*}{ RM250-2080 } & 0 & 0.043 & 0.78 & 0.94 \\
\hline & 6 & 0.055 & 0.74 & 0.88 \\
\hline & 9 & 0.082 & 0.70 & 0.77 \\
\hline & 12 & 0.110 & 0.61 & 0.69 \\
\hline \multirow[t]{4}{*}{ IRATOM } & 0 & 0.080 & 0.68 & 0.96 \\
\hline & 6 & 0.110 & 0.60 & 0.85 \\
\hline & 9 & 0.133 & 0.50 & 0.64 \\
\hline & 12 & 0.150 & 0.43 & 0.48 \\
\hline F-test & & $* *$ & $*$ & $*$ \\
\hline $\operatorname{LSD}_{(0.05)}$ & & 0.028 & 0.090 & 0.073 \\
\hline CV (\%) & & 10.89 & 9.60 & 6.48 \\
\hline
\end{tabular}

It may be concluded that all the studied rice mutants were variably affected in morpho-physiological attributes and yield contributing characters by different levels of salinity; and among the mutants, RM250-2080 and RM250-170 were found comparatively more tolerant under $12 \mathrm{dSm}^{-1}$ saline conditions than the other genotypes with less TDM and yield reduction. Therefore, these two mutants may have adopted themselves in moderate saline condition after few more field trials.

\section{Acknowledgement}

The authors are grateful to the Ministry of Higher Education, Malaysia for providing financial support from Long-Term Research Grant Scheme (LRGS) to carry out the experiments and also for providing publication cost. 


\section{References}

Alamgir, A. N. M. and Ali, M. Y. 1998. Growth of rice genotypes under salinity stress. Chittagong Univ. J. Sci., 22: 47-53.

Cristo, E.; Gonzalez, M. C.; Cardenas, R. M. and Perez, N. 2001. Salinity tolerance evaluation at the young stage of three new rice lines by morpho-agronomic markers. Cultivars Trop., 22: 43-45.

Dionisio-Sese, M. L. and Tobita, S. 2000. Effects of salinity on sodium content and photosynthetic responses of rice seedlings in salt tolerance. J. Plant Physiol., 157: 54-58.

Flowers, T. J. 2004. Improving crop salt tolerance. $J$. Exp. Bot., 55: 307-319.

Gorney, A. G. and Larson, S. 1989. New aspect in root breeding. Proc. III. Congress of Eucarpia Goltingen, Germany. p. 339-356.

Islam, M. S.; Molla, A. H. and Quayum, H. A. 2004. Effect of different levels of salinity on grain filling in rice. Bull. Inst. Trop. Agric., Kyushu Univ., 24: 19-22.

Islam, M. Z.; Baset Mia, M. A.; Akter, A. and Rahman, M. H. 2007. Biochemical attributes of mutant rice under different saline levels. Int. J. Sustain. Crop Prod., 2: 17-21.

Karim, M. A.; Nawata, E. and Shigenaga, S. 1992. Dry matter production and distribution of mineral ions in different parts of the plant in hexaploid triticale under salt stress conditions. Jpn J. Crop Sci., 61: 439-446.

Mahmood, A.; Latif, T. and Khan, M. A. 2009. Effect of salinity on growth, yield and yield components in Basmati rice germplasm. Pak. J. Bot., 41: 3035-3045.
Maiti, R. K.; Vidyasagar, P and Banerjee, P. P. 2008. Characterization of salinity tolerance in rice genotypes at the germination and seedling stages. Indian J. Agric. Res. 57: 114-117.

Mondal, M. M. A.; Puteh, A. B.; Malek, M. A. and Rafii, M. Y. 2013. Salinity induced morphophysiological characters and yield attributes in rice genotypes. J. Food Agric. Environ., 11: 610-614.

Moradi, F. and Ismail, A. M. 2007. Response of photosynthesis, chlorophyll florescence and ROS-scavenging system to salt stress during seedling and reproductive stage in rice. Ann. Bot., 99: 1163-1173.

Natarajan, S. K.; Ganapathy, M.; Nagarajan, R. and Somasundaram, S. 2005. Screening of rice accessions for yield and yield attributes contributing to salinity tolerance in coastal saline soils of Tamil Nadu, India. Asian J. Plant Sci., 4: 435-437.

Pandey, U. K. and Sharma, A. P. 2002. Effect of salinity on potassium, calcium and magnesium content in rice varieties. Indian J. Plant Physiol., 7: 302-304.

Reddy, M. P. and Vora, A. B. 1986. Changes in pigment composition, hill reaction activity and saccharides metabolism in bajra leaves under $\mathrm{NaCl}$ salinity. Photosynthica, 20: 5055 .

Summart, J.; Thanonkeo, P.; Panichajakul, S.; Prathepha, P. and McManus, M. T. 2010. Effect of salt stress on growth, inorganic ion and proline accumulation in Thai aromatic rice. African J. Biotech., 9: 145-152. 